\title{
Phytoremediation of soil polluted with Iraqi crude oil using grass plant
}

\author{
Abdul Hameed Al-Obaidy ${ }^{1}$, Riyad Al-Anbari ${ }^{2}$, Sarah Hassan ${ }^{2}$ \\ ${ }^{1}$ Environmental research Center, University of Technology, Baghdad, Iraq \\ ${ }^{2}$ Department of Building and Construction Engineering, University of Technology, Baghdad, Iraq
}

\begin{abstract}
Remediation technology is a promising technique that decreases pollutants like hydrocarbons from the environment. An experimental work was done at green house of University of Technology in order to study the effect of crude oil on the plant growth and to measure the decrement which happened on shoot height, germination rate and the reduction of total petroleum hydrocarbon (TPH), which resulted by this phytoremediation technique. The samples of soil were measured for TPH reduction and removal by Horiba model OCMA - 350. Five doses were used in this experiment ( 0 control, 10x103, 30 x103, 50 x103, 75 $\mathrm{x} 103$ ) (mg crude oil / $\mathrm{kg}$ soil) or (ppm). The greater efficiency was obtained in the treatment $50 \mathrm{x} 103 \mathrm{ppm}$ seeded with cotton, in which cotton removed $50.66 \%$ of the primary TPHs from soil. Results showed that the employed vegetate species were promising and effective in reducing and removing TPHs from freshly polluted soil.
\end{abstract}

\section{Introduction}

Pollution that had been found in the used agricultural lands is serious trouble contributed by the processing and allocation of crude oil and refined petroleum output in many oil producing countries [1]. As these problems are becoming bigger day by day, the solution must be found to clean up the pollution and this has led to exploration of many remedial approaches including physical and chemical methods to reduce the pollution. However it was found that such techniques aggravated the problem rather than eliminating it. Biodegradation method is used now a days because its being a good option for the remediation of polluted sites mainly because it uses inexpensive equipment, friendly to the environment and simple.

The experimental soil was chosen and collected from location without oil contamination. Then, Iraq crude oil, which was supplied and analyzed, was used to contaminate the selected soil. The following treatments were used in the experimental study:
One of the most effective techniques in the biodegradation is phytoremediation where it employed vegetates and microbes for the remediation of contaminated sites.

Many research studies evaluated the phytoremediation technique to remediate petroleum polluted lands [2],[3],[4]. Many vegetates were also studied to know if they have phytoremediation potential to remove and decrease petroleum contaminants from soil [5],[6],[7].

In this study grass was used for the phytoremediation of the crude oil. This research shows the effect of different concentrations of crude oil on the plant development and germination.

\section{Material and methods}

T1: Unpolluted soil (control) sown with selected plant seeds and without seeded plant.

T2: Polluted soil with crude oil (10000 ppm, 30000 ppm, 50000 ppm and 75000 ppm) sown with seeded plants and without seeded plant. 
Control soil was used to show the degradation of crude oil by microorganisms without the plant effect and compared it with planted pots to see the effect of plant on degradation. Petroleum hydrocarbon pollution have negative impact on the plant growth, which was discover by this comparison. In this research sieve of $2 \mathrm{~mm}$ was used to sieve soil. After mixing the soil homogeneously, the weighed soils were transmitted to PVC pots (7 $\mathrm{kg}$ of soil per pot).

Plants were seeded in contaminated soil as well as unpolluted soil. Then the TPH concentration was measured in control and contaminated soil with one vegetation species was employed in this research. However, like we know, natural processes can be used to reduce concentration of TPHs such as microbial action in soil. It appears that, even if the contaminated soil is ignored and neglected without any treatment or remediation effort, TPH level will reduce after some time. The effect of phytoremediation itself should be separated from the natural processes, which is called "Natural Attenuation". Therefore, in this study, natural attenuation (NA) treatment was also considered for TPHs reduction. Grass was seeded in soils T1 and T2 for 5 month duration in a greenhouse. Plants were vegetated in a height of $1-1.5 \mathrm{~cm}$ in the upper layer of soil in the each pot. The pots were put into the greenhouse beneath the sunlight. The plants were irrigated two times a week to keep sufficient and constant humidity level and to decrease the outgoing of leachate [11].

The temperature was between $25^{\circ} \mathrm{C}$ and $35^{\circ} \mathrm{C}$. Leachate was collected by PVC pans kept beneath each

\section{Results}

A promising behavior is shown by the vegetated species that was employed in this phytoremediation research in removing petroleum hydrocarboncontaminated soil. Because of the oil pollution plant pot. The collected water from the pans was put in the next irrigation to avoid the loss of the petroleum crude oil. However, only $0.02 \%$ of the TPH in soil was leaked out from the container with the excessive water that got down to the pans [12]. The number of developed vegetates or the upper layer of soil density was monitored to see the germination rate in the first weeks. The shoot height was monitored and measured.

Core sampler (inner diameter $=10 \mathrm{~mm}$ ) was used to take soil samples from the $5 \mathrm{~cm}$ depth of the container in each month of study. For TPH measurement, soil samples were air dried by putting it at normal room temperature and sieved with a $2 \mathrm{~mm}$ sieve. There are various procedures, which will accurately measure TPH in soil. This method is provided as a simple procedure for Horiba model OCMA - 350 oil concentration monitoring and analysis. Samples of $5 \mathrm{~g}$ of soil were taken and put in $40 \mathrm{ml}$ clean vial. $1 \mathrm{~g}$ of anhydrous sodium sulfate, $\mathrm{Na}_{2} \mathrm{SO}_{4}$ was added to dry the soil samples.

$30 \mathrm{ml}$ of solvent (infrared spectrometer grade of Horiba S-316) were added to the vials. An extraction of oil in soil to oil in solvent was performed by shaking the vials vigorously for one or more minutes. After shaking the vials were placed in its upright position and waited for at least one min to allow setting of soil particles. $11 \mathrm{~cm}$ No 40 Whatman filter paper was put in glass funnel. $2 \mathrm{gm}$ of conditioned silica gel was added above the filter paper. The solvent / extract was filtered through the filter into a clean beaker. Pipette about $6 \mathrm{ml}$ of extract into the OCMA-350 cell. Placed the cell into the OCMA -350 and measured.

development was depressed to some extent. Shoot heights of the studied plants at the beginning, middle and end of the study are showed in Figures 1. 


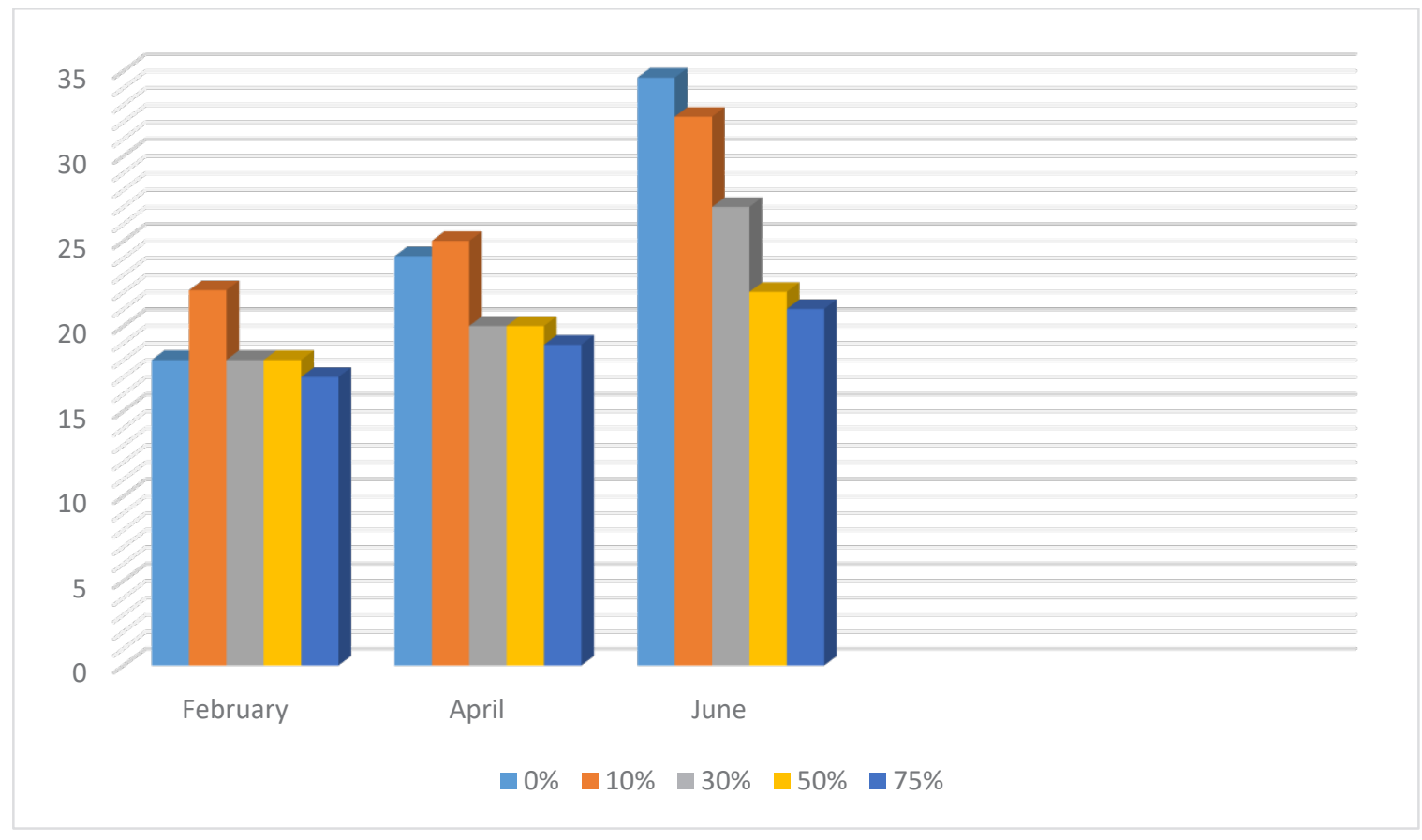

Fig. 1. Shoot height monitoring during phytoremediation.

Seedling germination of grass was reduced by the petroleum hydrocarbons present in the soil (Figure 2 ). The plant shoot heights vegetated in oil-polluted soil have shorter height in compare with the shoot heights of the plants grown in clean soil.

The decrease of TPH concentration was shown in table (1). The impact of the observed plant on petroleum hydrocarbon elimination at specific period of times was monitored. The seeded plant caused a significantly higher petroleum hydrocarbon dispersion in comparison with un-vegetated soil. Natural attenuation capable of minimize the polluted degree by TPH in soil by $(76.19 \%, 86.5 \%, 86.21 \%$, and $77.8 \%$ ) for $\left(75 \times 10^{3}, 50 \times 10^{3}, 30 \times 10^{3}, 10 \times 10^{3}\right)$ ppm respectively crude oil concentrations when the study ended. The highest effectiveness of phytoremediation was achieved for grass, in which plant existed in comparison with natural attenuation reduced the TPH level by $(90.47 \%$, $90 \%, 89.73 \%, 84.42 \%)$ for $\left(75 \times 10^{3}, 50 \times 10^{3}, 30 \times 10^{3}\right.$, $10 \times 10^{3}$ ) ppm respectively. Table (3) presented the TPH removal rate at one-time intervals. TPH dispersion in S2 with the existing plant was greater in the whole five months. This drift was also studied for natural attenuation. The least TPH depression rate was observed in the final month. 
Table 1. TPH removal rate in different treatments (mg kg-1).

\begin{tabular}{|c|c|c|c|}
\hline $\begin{array}{l}\text { Different concentration of crude } \\
\text { oil with plant }\end{array}$ & $\begin{array}{l}\text { TPH concentration reduction } \\
\text { by soil seeded with plant } \\
\text { For five months } \\
(\mathrm{mg} / \mathrm{kg})\end{array}$ & $\begin{array}{l}\text { Concentration of TPH Removed } \\
\text { by plant } \\
(\mathrm{mg} / \mathrm{kg})\end{array}$ & $\begin{array}{l}\text { Removal rate by } \\
\text { plant } \\
(\%)\end{array}$ \\
\hline$\% 0$ & 0 & - & - \\
\hline$\% 10$ & 610-105 & 292 & $\% 47.8$ \\
\hline$\% 30$ & 994-39 & 496 & $\% 49.9$ \\
\hline$\% 50$ & $3876-786$ & 1964 & $\% 50.6$ \\
\hline$\% 75$ & $4368-1610$ & 1130 & $\% 25.8$ \\
\hline $\begin{array}{l}\text { Natural Attenuation } \\
\text { (soil without plant) }\end{array}$ & $\begin{array}{c}\text { TPH concentration reduction } \\
\text { by soil } \\
\text { For five months } \\
(\mathrm{mg} / \mathrm{kg})\end{array}$ & $\begin{array}{l}\text { TPH Removed by soil } \\
\qquad(\mathrm{mg} / \mathrm{kg})\end{array}$ & $\begin{array}{c}\text { Removal rate by } \\
\text { soil } \\
(\%)\end{array}$ \\
\hline$\% 0$ & 0 & - & 0 \\
\hline$\% 10$ & $610-397$ & 213 & $\% 34.9$ \\
\hline$\% 30$ & $994-535$ & 459 & $\% 46.1$ \\
\hline$\% 50$ & $3876-2750$ & 1126 & $\% 29$ \\
\hline$\% 75$ & $4368-2740$ & 1628 & $\% 37.2$ \\
\hline
\end{tabular}

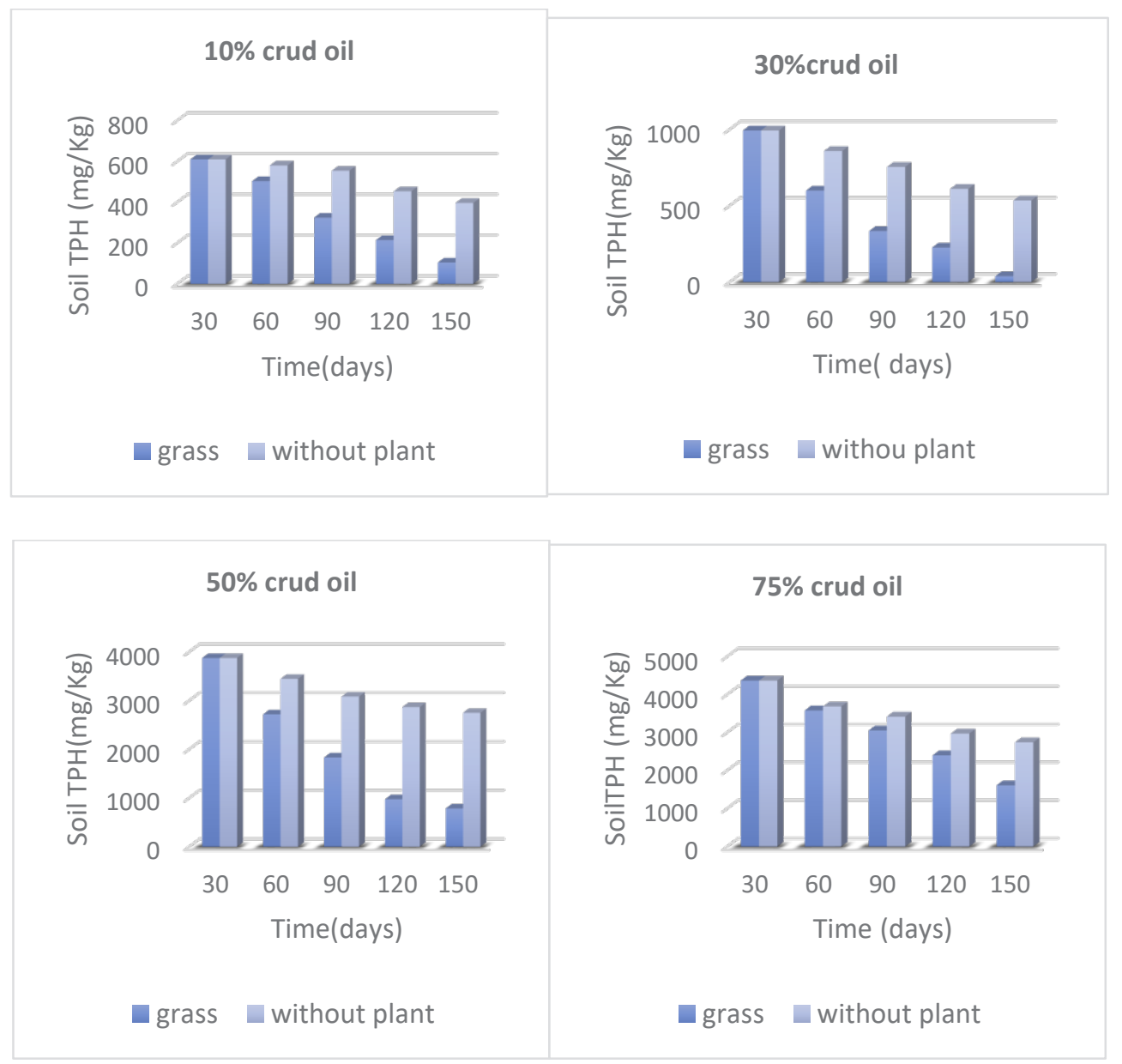

Fig. 2. TPH concentration for five months. 


\section{Discussion}

A promising behavior was showed by the plant species, which were used in the current phytoremediation study in petroleum hydrocarbonpolluted area. However, the plant development was affected in the oil polluted soil to some extent. The most substantial point in plant establishment is the development rate. Germination Sensitivity is also the first developmental step of seeding plant can influence the efficiency of phytoremediation. A relationship between poor emergence and subsequent poor development in hydrocarbon-polluted area was mentioned by some researchers [10].

An adverse effect and delay caused by the increase of petroleum hydrocarbon concentration on the development of the observed plant species; in addition, the subsequent evolution was frustrated greatly in most cases by petroleum hydrocarbon contamination.

The soil employed in this research was fresh soil, refers to the fresh oil pollution. The water repellent characteristic of hydrocarbons may be the cause of development delay of the studied plants. Delaying or preventing the access of water and oxygen to seeds may be caused by the Hydrocarbons, act as physical barrier [8].

The presence of petroleum hydrocarbon made a remarkable reduction of shoot height, which was observed for cotton plants. The effects of toxicity of petroleum crude oil caused an inhibition of plant growth. Small molecules of hydrocarbons can enter and pass cell membranes leading to reduced membrane integrity or even to the death of the cell [13].

Plant health can be indicated by plant height and shoot biomass; however, more shoot biomass observed in the study is not necessarily an indicative of enhanced remediation efficiency [9]. Extensive root elongation is likely to be associated with more root biomass within the soil.

It was observed that the studied plants increase the removal rate of petroleum hydrocarbon at varied sampling times. The seeded plant made significantly higher petroleum hydrocarbon dispersion in contrast with unplanted soil.

Based on the obtained results, cotton is a promising species for phytoremediation of fresh petroleum hydrocarbon-contaminated soils. However, plants growth was depressed by petroleum hydrocarbon contamination. Cotton as we know, it is easy to vegetate in many countries. Remediation is well known as inexpensive and requires minimum maintenance technology which is why it is used in Iraq and most other developing countries.

\section{References}

1. J. Ayotamuno, R. Kogbara, M. Taleat, Bioremediation of a petroleum-hydrocarbon polluted agricultural soil at different levels of water application in Port Harcourt, Nigeria. J Food, Agric. Environ. 4 (3\&4): 214-217, (2006)

2. N. Merkl,, R. Schutze-Kraft, C. Infante, Phytoremediation in the tropics - influence of heavy crude oil on root morphology characteristics of graminoids. Environ. Poll., 138(1): 86-91(2005).

3. I. Issoufi,, R.L. Rhykerd, K.D. Smiciklas, Seedling growth of agronomic crops in crude oil contaminated soil. J. Agron. Crop Sci., 192: 310 (2006).

4. E. Diab., Phytoremediation of Oil Contaminated Desert Soil Using the Rhizosphere Effects. Global J. Environ. Res., 2(2): 66-73 (2008).

5. C.M. Frick, R.E. Farrell, J.J. Germida, Assessment of Phytoremediation as an in situ technique for cleaning oil-contaminated sites. Petroleum Technology Alliance Canada, Calgary. (1999).

http://www.rtdf.org/pub/phyto/phylinks.htm.

6. K. Njoku, M. Akinola, B. Oboh, Growth and Performance of Glycine max L. (Merrill) Grown in Crude Oil Contaminated Soil Augmented With Cow Dung. Nat. Sci., 6(1): 46-56 (2008). 
7. K. Njoku, M. Akinola, B. Oboh, Phytoremediation of crude oil contaminated soil: the effect of growth of Glycine max on the physico-chemistry and crude oil contents of soil. Nat. Sci., 7(10): 79-87. (2009).

8. G. Adam, H. Duncan, Influence of diesel fuel on seed germination. Environ Pollut 120: 363-370. (2002). 9. M. Banks, P. Schwab, B. Liu, , Kulakow, P., Smith, J.S., Kim, R, The effect of plants on the degradation and toxicity of petroleum contaminants in soil: A field assessment. Adv Biochem Eng Biotech 78: 75-96. (2003).

10. C. Chaineau, J. Morel, J. Oudot, Phytotoxicity and plant uptake of fuel oil hydrocarbons. J Environ Qual 26: 1478- 483. (1997)

11. J.Tiba .,J. Abdul Hameed .,A. Riyad, The Use of Phytoremediation Technique to Remove Cr and Pb Ions from Soil Irrigated with Wastewater . (2013)

12. S. Hutchinson, M. Banks, A. Schwab, Phytoremediation of aged petroleum sludge: Effect of inorganic fertilizer. J Environ Qual 30: 395-403. (2001) 13. N. Merkl , R. Schultze-Kraft.,C. Infante, Phytoremediation in the tropics-the effect of crude oil on the growth of tropical plants. Biorem J 8: 177-184. (2004). 